Prepared for the U.S. Department of Energy

under Contract DE-AC05-76RL01830

\title{
Wynkoop Building Performance Measurement: Water
}

KM Fowler

AR Kora

August 2012

Pacific Northwest

NATIONAL LABORATORY

Proudly Operated by Battelle Since 1965 


\title{
DISCLAIMER
}

This report was prepared as an account of work sponsored by an agency of the United States Government. Neither the United States Government nor any agency thereof, nor Battelle Memorial Institute, nor any of their employees, makes any warranty, express or implied, or assumes any legal liability or responsibility for the accuracy, completeness, or usefulness of any information, apparatus, product, or process disclosed, or represents that its use would not infringe privately owned rights. Reference herein to any specific commercial product, process, or service by trade name, trademark, manufacturer, or otherwise does not necessarily constitute or imply its endorsement, recommendation, or favoring by the United States Government or any agency thereof, or Battelle Memorial Institute. The views and opinions of authors expressed herein do not necessarily state or reflect those of the United States Government or any agency thereof.

\author{
PACIFIC NORTHWEST NATIONAL LABORATORY \\ operated by \\ BATTELLE \\ for the \\ UNITED STATES DEPARTMENT OF ENERGY \\ under Contract DE-AC05-76RL01830 \\ Printed in the United States of America \\ Available to DOE and DOE contractors from the \\ Office of Scientific and Technical Information, \\ P.O. Box 62, Oak Ridge, TN 37831-0062; \\ ph: (865) 576-8401 \\ fax: $(865)$ 576-5728 \\ email: reports@adonis.osti.gov \\ Available to the public from the National Technical Information Service \\ 5301 Shawnee Rd., Alexandria, VA 22312 \\ ph: (800) 553-NTIS (6847) \\ email: ordersantis.gov <http://www.ntis.gov/about/form.aspx> \\ Online ordering: http://www.ntis.gov
}

This document was printed on recycled paper.

(8/2010) 


\section{Wynkoop Building Performance Measurement: Water}

KM Fowler

AR Kora

August 2012

Prepared for

the U.S. General Services Administration

under Department of Energy Contract DE-AC05-76RL01830

with Battelle Memorial Institute

Pacific Northwest National Laboratory

Richland, Washington 99352 


\section{Table of Contents}

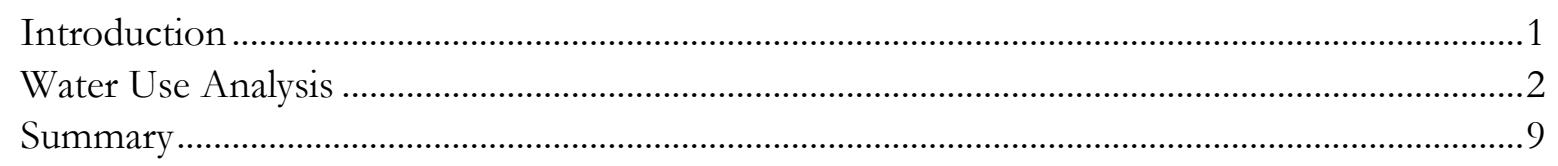

Figures

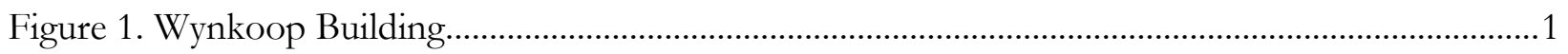

Figure 2. LEED-NC Point Summary ………....................................................................................

Figure 3. Wynkoop Water Use (gallons per gross square foot) .............................................................2

Figure 4. $7^{\text {th }}$ Floor Event Occurrences Before and After Toilet Handle Retrofit .................................. 4

Figure 5. $5^{\text {th }}$ Floor Event Occurrences Before and After Toilet Handle Retrofit ..................................5

Figure 6. $5^{\text {th }}$ Floor Toilet Flush Test Results (volume per flush) ...........................................................6

Figure 7. $2^{\text {nd }}$ Floor Toilet Flush Test Results (volume per flush) …………............................................6

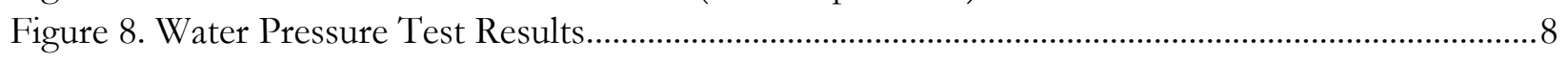




\section{Introduction}

This report is a summary of the water analysis performance for the Denver, Colorado Wynkoop Building. The Wynkoop Building (Figure 1) was built in 2006 as the Environmental Protection Agency (EPA) Region 8 Headquarters intended to house over 900 occupants in the 301,292 gross square feet $(248,849$ rentable square feet). The building was built on a brownfield in the Lower Downtown Historic District as part

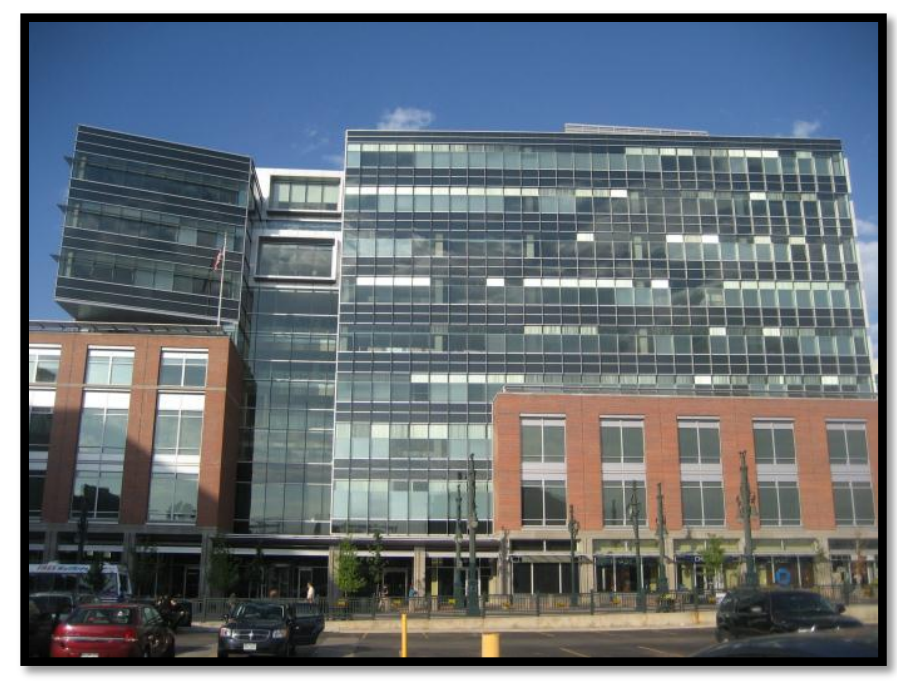

Figure 1. Wynkoop Building of an urban redevelopment effort. The building was designed and constructed through a public-private partnership with the sustainable design elements developed jointly by General Services Administration (GSA) and EPA. That partnership is still active with all parties still engaged to optimize building operations and use the building as a Learning Laboratory.

The building design achieved U.S. Green Building Council Leadership in Energy and Environmental Design for New Construction (LEED-NC) Gold Certification in 2008 (Figure 2) and a 2008 EPA Energy Star Rating of 96 with design highlights that include:

\section{LEED $\circledast$ - NC v2.1}

EPA Region 8 Headquarters

1595 Wynkoop Street, Denver, Colorado 80202-9999

\section{Gold}

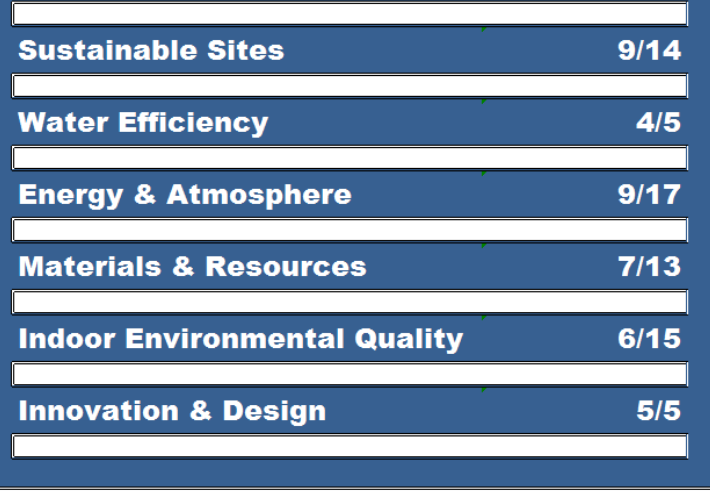

Certified: 26-32 points, Silver: 33-38 points, Gold: 39-51 points, Platinum: 52-69 points

Figure 2. LEED-NC Point Summary
- Water use was designed to use $40 \%$ less than a typical design baseline. The design included low flow fixtures, waterless urinals and dual flush toilets.

- Native and adaptive vegetation were selected to minimize the need for irrigation water for landscaping.

- Energy use intensity was modeled at $66.1 \mathrm{kBtus} /$ gross square foot, which is $39 \%$ better than ASHRAE 90.11999. 


\section{Water Use Analysis}

Wynkoop was designed with dual flush toilets, low flow fixtures, and water free urinals. The design features earned the building four of five Water Efficiency points in the LEED-NC certification with predicted water use at over $40 \%$ less than a typical water fixture design. Other water uses in the building that were not included in the calculations for LEED-NC certification include an indoor fountain, an irrigated green roof, and heating, ventilation and air-conditioning related process water. The designed fixture water use only was calculated to be 1,262,664 gallons per year or 4.2 gallons per gross square foot (GSF). The first year of water use was notably higher than anticipated. The building process water was submetered, which identified process water use as the primary source of the unexpected level of water use. The building managers adjusted the building steam system, reducing tempering water at the drain, putting the water use back into an expected range. Since that fix, the building water use was measured lower than the water use index (WUI) industry average of 15 gallons/gross square foot ${ }^{1}$ and lower than GSA targets of 13.3 gallons/gross square foot for the GSA Green Building Average, and 13 gallons/gross square foot for the GSA 2015 goal (see Figure 3).

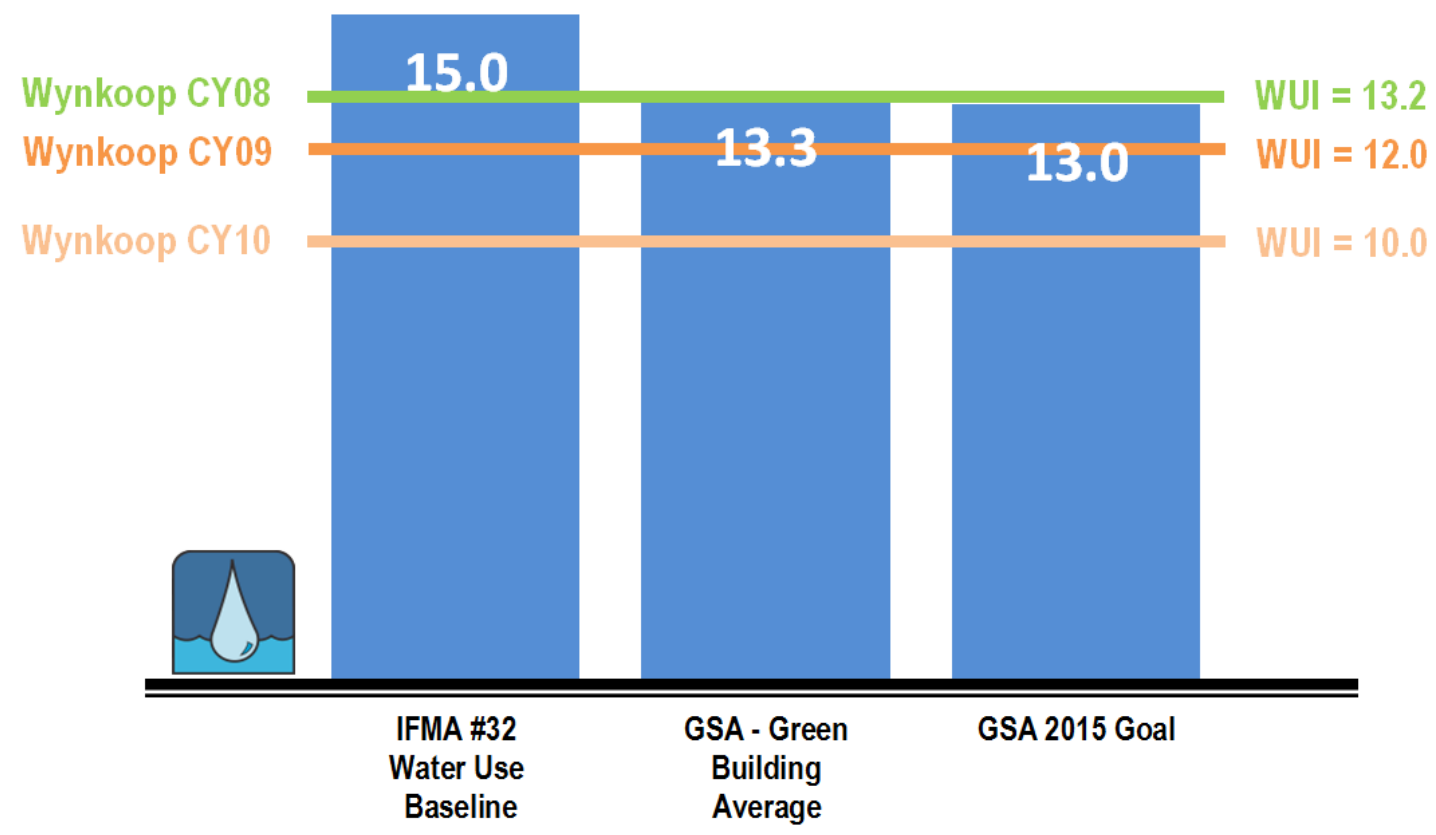

Figure 3. Wynkoop Water Use (gallons per gross square foot)

${ }^{1}$ International Facility Management Association (IFMA). 2009. Operations and Management Benchmarks \#32. IFMA, Houston, Texas. 
Since the Wynkoop Building has other water uses outside of bathroom fixtures, the design calculation method used in LEED-NC (fixtures only) does not represent the whole building's water use. The type of occupants and number of occupants can have a significant impact on fixture water use as well. Given that, it is not surprising the measured water use was higher than the LEED-NC calculated design values, however, the water use still appeared to be higher than the building operators expected after addressing the steam condensate issue, which prompted water use analysis focused on fixture use.

In March 2011, Koeller and Company used one meter to collect metered data for the $7^{\text {th }}$ floor men's and women's restrooms in one second intervals in order to capture short water use events and determine average volume per event. The men's and women's toilets were fed by the same water line and thus could not be metered separately so gender differences could not be captured. Based on the $7^{\text {th }}$ floor metered data, a toilet handle retrofit was implemented on the $7^{\text {th }}$ floor. Additional metered data was collected on the $7^{\text {th }}$ floor in June and July 2011 after the toilet handle retrofit was installed. After metering the $7^{\text {th }}$ floor, it was determined that metering other floors may be useful in answering the water consumption questions.

In November and December 2011 PNNL worked with the Wynkoop Building management to install additional meters and monitor water use on the $2^{\text {nd }}, 3^{\text {rd }}$, and $5^{\text {th }}$ floors. The $2^{\text {nd }}$ floor was metered to better understand water use by visitors using the large conference center on the $2^{\text {nd }}$ floor. The $3^{\text {rd }}$ floor fitness center was metered to better understand fitness center water use. The $5^{\text {th }}$ floor restrooms were metered to further validate the preliminary savings experienced on the $7^{\text {th }}$ floor. Data was collected in one second intervals, similarly to the approach on the $7^{\text {th }}$ floor. Water pressure readings were also taken on each floor.

From the data collected in this analysis, Wynkoop water use findings can be summarized as:

- Dual flush toilet performance varies

- Restroom use by visitors on the $2^{\text {nd }}$ floor is minimal

- Shower use is primarily hot water

- Water pressure varies floor to floor

\section{Dual flush toilet performance varies}

March 2011 measurements from the $7^{\text {th }}$ floor indicated that occupants appeared to not be using the dual flush toilet handles as designed. The original handles were designed as a full flush (1.1 gallons) when pushed down, and a reduced flush (0.8 gallons) when pulled up. As illustrated in

Figure 4, the majority of the water use events were greater than 1 gallon per flush, indicating mostly full flushes (pushed down). Because of this finding, building management retrofitted 
the toilets with handles that reversed the flush, that is, reduced flush when pushed down, and full flush when pulled up.

Figure 4 shows that after the retrofit, the majority of the water use events were less than 1 gallon, indicating that the majority of flushes were reduced flush mode (pushed down).

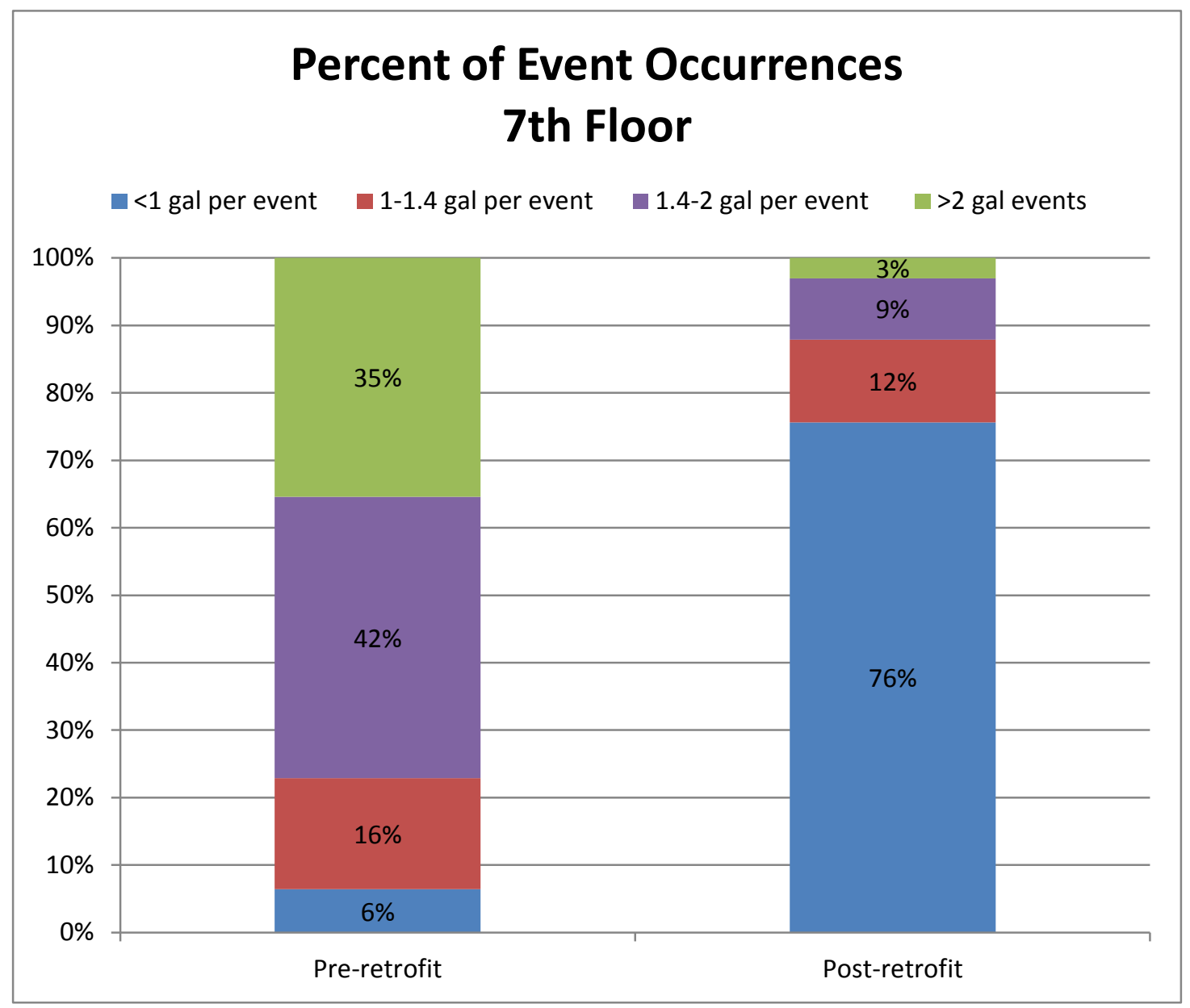

Figure 4. $7^{\text {th }}$ Floor Event Occurrences Before and After Toilet Handle Retrofit

The average volume per event decreased nearly $70 \%$ from 2.3 gallons per event to 0.7 gallons per event. Because of the positive results of this handle retrofit on the $7^{\text {th }}$ floor, building management retrofitted the toilet handles throughout the building.

Metered data from $5^{\text {th }}$ and $2^{\text {nd }}$ floors did not show the same level of water savings as was seen on the $7^{\text {th }}$ floor.

Figure 5 illustrates that there were minimal differences in the before and after retrofit data on the $5^{\text {th }}$ floor. Of the $5^{\text {th }}$ floor, the aggregate average volume per event decreased by about $5 \%$, from 0.88 gallons per event to 0.84 gallons per event. 


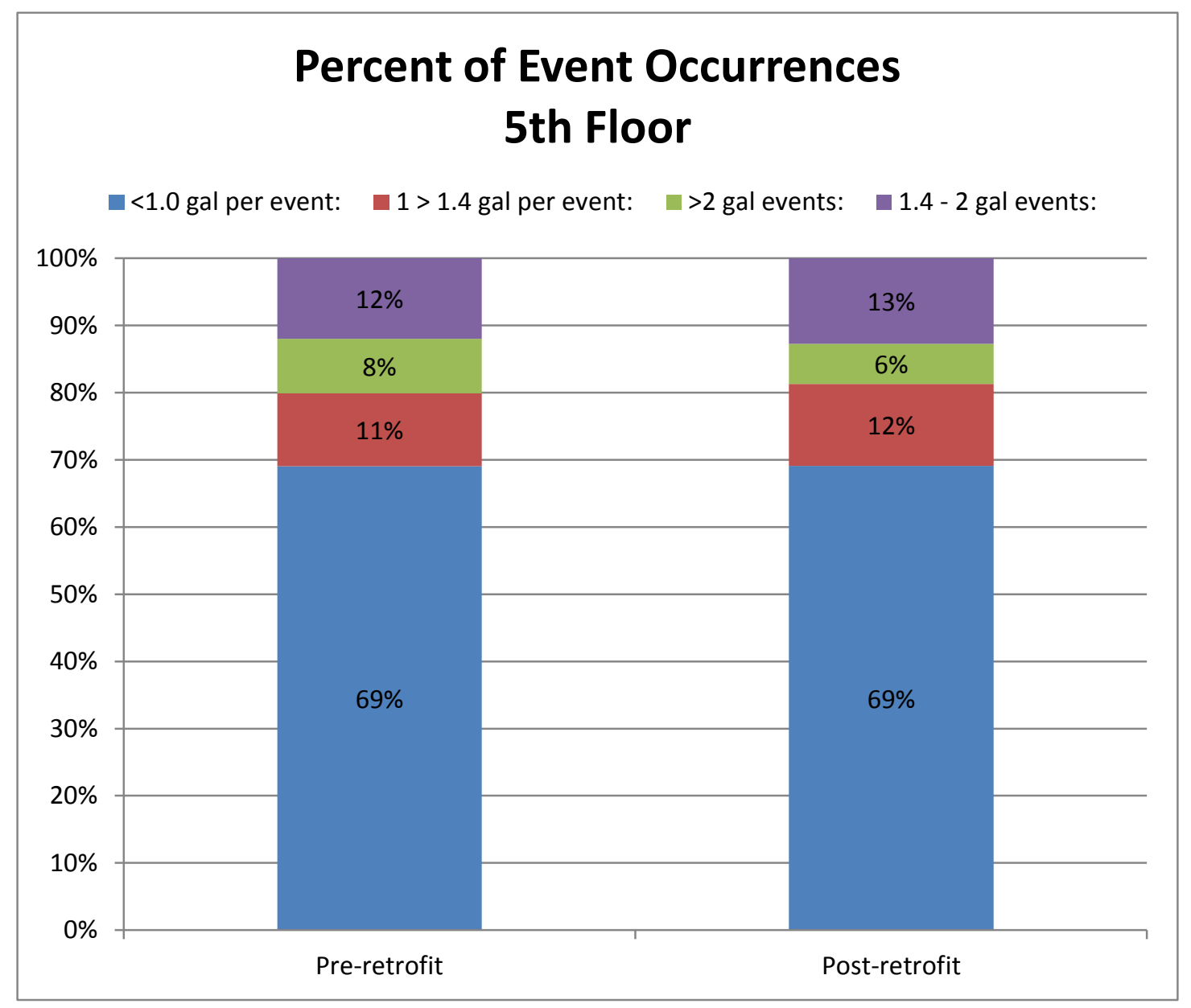

Figure 5. $5^{\text {th }}$ Floor Event Occurrences Before and After Toilet Handle Retrofit

The $2^{\text {nd }}$ floor restrooms were not used frequently enough during the metering period to generate data that could be compared to the $7^{\text {th }}$ and $5^{\text {th }}$ floors.

In addition to analyzing aggregate data, toilet flush tests were completed on the $2^{\text {nd }}$ and $5^{\text {th }}$ floors to develop profiles of an average full and reduced flush. The results of these flush tests are shown in

Figure 6 and

Figure 7.

Figure 6 illustrates that on the $5^{\text {th }}$ floor, the average flush volume for the full and reduced flush was the same before and after the retrofit, 1.2 and 0.9 gallons per flush respectively. 


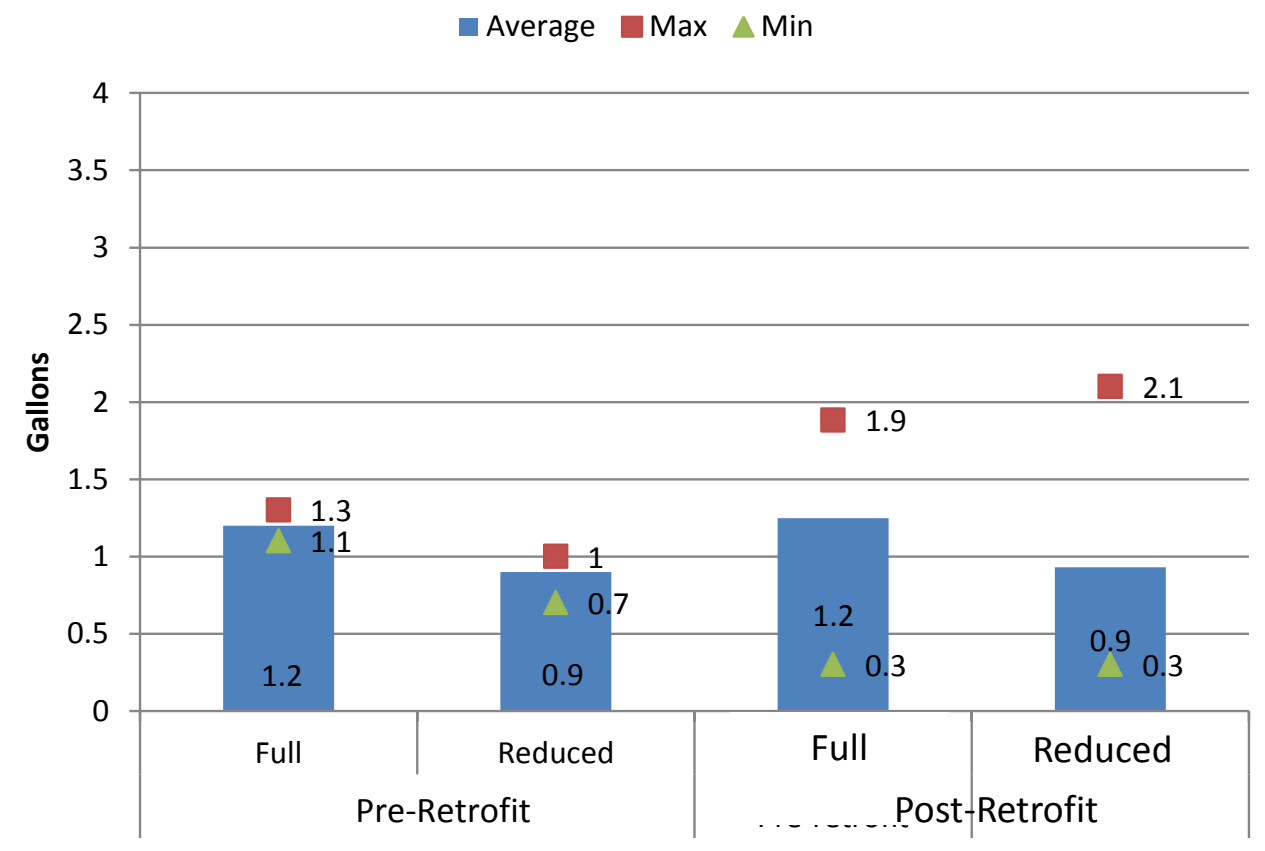

Figure 6. $5^{\text {th }}$ Floor Toilet Flush Test Results (volume per flush)

Figure 7 illustrates a more noticeable difference in the average pre-and post-data on the $2^{\text {nd }}$ floor. 


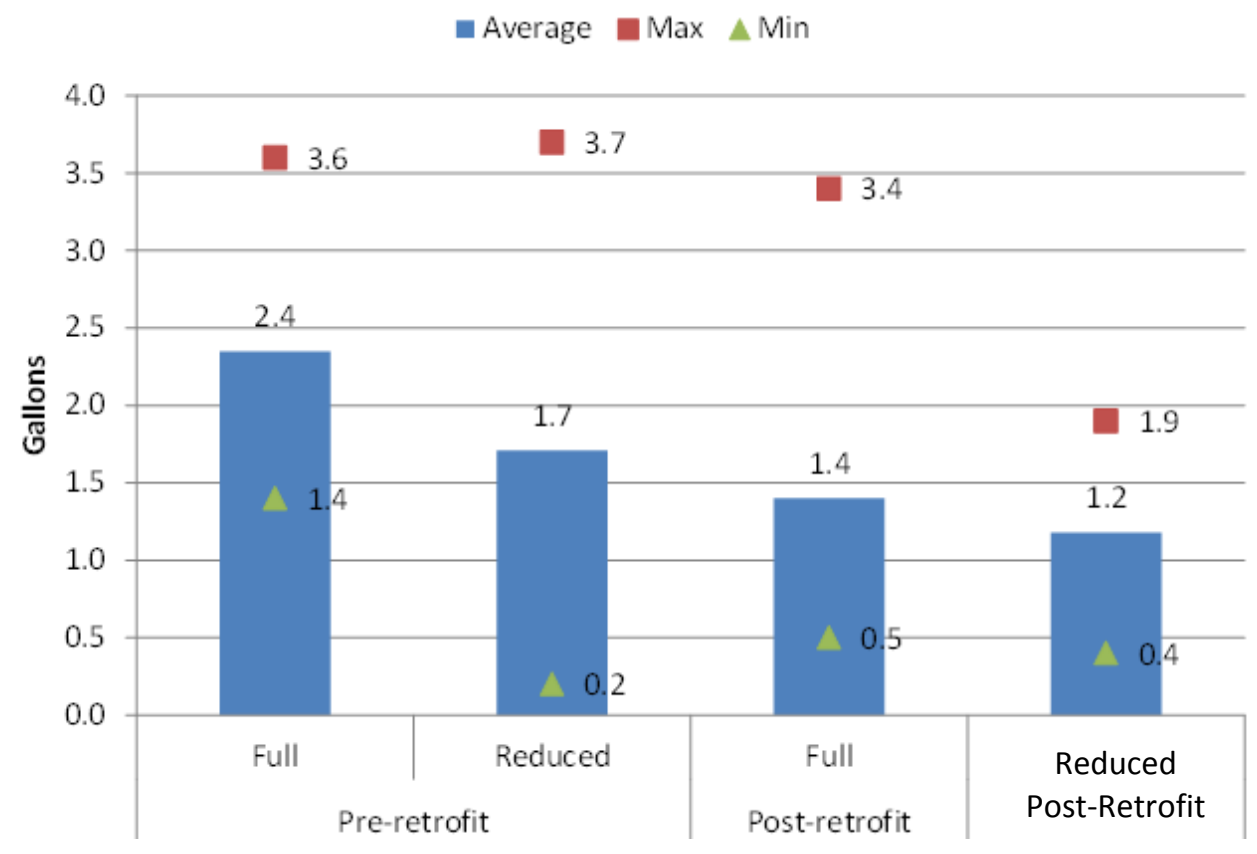

Figure 7. $2^{\text {nd }}$ Floor Toilet Flush Test Results (volume per flush)

The variability in the toilet performance on the $7^{\text {th }}, 5^{\text {th }}$, and $2^{\text {nd }}$ floors might be related to the technology choice. Other Federal water assessments have indicated that diaphragm-type valves (the type of valve installed in the Wynkoop Building restrooms) are less reliable than piston-type valves, especially at low pressures. ${ }^{2}$ Commissioning the fixtures when installed would have ensured that the differences in measured data were because of occupancy use, rather than equipment or installation differences.

\section{Restroom use by visitors is minimal}

The $2^{\text {nd }}$ floor West restroom was metered to understand what impact visitors have on total water use in a building. The West restroom was selected because it is typically the more frequently used restroom. Total water use per day was collected for four days and compared to daily visitor logs. Water use per visitor was an estimated 0.08 gallons per visitor, and indicated that about one in ten visitors use the restroom. For comparison, occupants on the $7^{\text {th }}$ floor averaged 2.3 gallons per person per day, while occupants on the $5^{\text {th }}$ floor averaged 1.3 gallons per person per day.

Note that the volume per visitor data is limited by the availability of accurate occupancy data. Daily visitor logs were available but the duration of each visit was unknown.

${ }^{2}$ Elam E, P Bassett, and KM Stoughton. 2010. Y-12 National Security Complex Water Assessment. Prepared for the Federal Energy Management Program by Water Savers, LLC and Pacific Northwest National Laboratory. PNNL -19919, Pacific Northwest National Laboratory, Richland, Washington. http://www1.eere.energy.gov/femp/pdfs/y12 lessonslearned.pdf 


\section{Showers use primarily hot water}

Both the hot water and cold water lines serving the men's fitness center were metered separately; the cold water meters showed little to no usage indicating that hot water is the primary water type used for showering. This finding was not wholly unexpected. Hot water at the Wynkoop Building is provided by a recirculation line supplied from a city-managed district steam system, and occupant and building management feedback has indicated that the water temperature does not reach temperatures where mixing with cold water is necessary.

Over a four day average, men's fitness center total water use ranged from 110 gallons per day to 235 gallons per day. The original intent of the water metering was to measure the women's fitness center in addition to the men's, but the piping layout was such that the desired metering point was not easily accessible. Reliable data regarding the number of fitness center users per day was also not available. While a sign-in sheet is provided in the fitness center to track users, building management indicated that the majority of users do not use the sign-in sheet. Proxy card data was not available due in part to security concerns. As a result, it was not possible to estimate how much of the total building water consumption was due to fitness center use.

\section{Water pressure varies floor to floor}

Historically, occupant feedback indicated that water pressure varied throughout the building, and was particularly low on the $5^{\text {th }}$ floor. The building is served by city supplied water pressure for floors 2-5; a booster pump supports proper water pressure on floors 6-9. The results from the water pressure readings taken on each floor are shown in

Figure 8 , and illustrate that water pressure varies floor to floor with a significant increase from the $5^{\text {th }}$ to $6^{\text {th }}$ floor. 


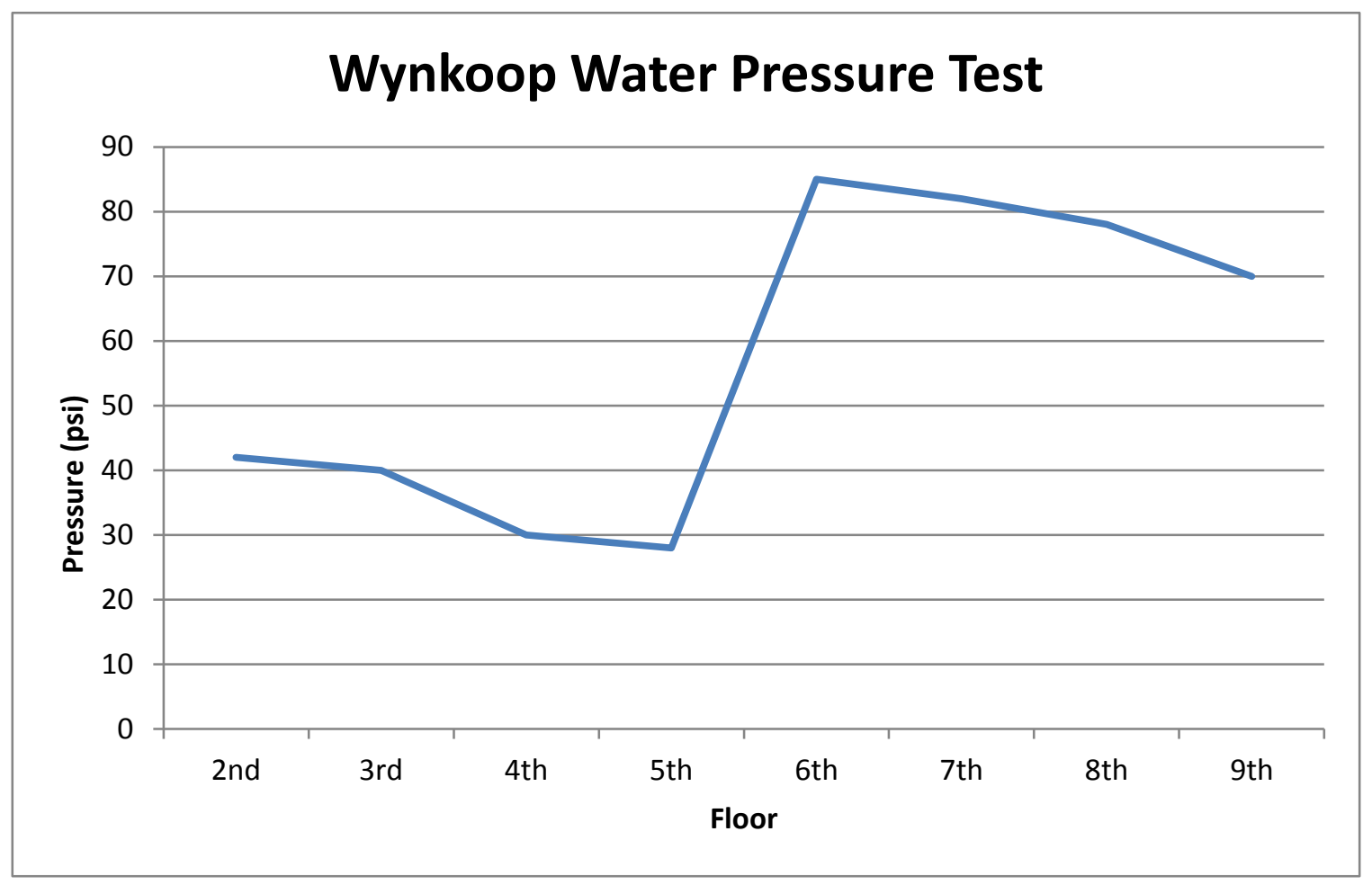

Figure 8. Water Pressure Test Results

This difference in water pressure could be one reason for the variances in fixture performance floor to floor identified in the $2^{\text {nd }}, 5^{\text {th }}$, and $7^{\text {th }}$ floor analysis.

This submetering effort identified additional questions to pursue in future research efforts, including:

- What solutions could be implemented to ensure more consistent floor to floor water pressure in high-rise buildings?

- To what extent does water pressure affect fixture performance (if any)?

- Are there more consistent water fixtures (piston vs. diaphragm valves, high efficiency toilets vs. dual flush)? 



\section{Summary}

The Wynkoop Building water use (10 gallons/square foot) was measured at lower than industry average (15 gallons/square foot) and GSA goals (13 gallons/square foot), however, it was higher than building management expected it would be. The type of occupants and number of occupants can have a significant impact on fixture water use. The occupancy per floor varied significantly over the study time period, which added uncertainty to the data analysis.

Investigation of the fixture use on the $2^{\text {nd }}, 5^{\text {th }}$, and $7^{\text {th }}$ floors identified potential for water use reduction if the flush direction of the dual-flush toilet handles was reversed. The building management retrofitted the building's toilets with handles that operated on reduced flush when pushed down ( 0.8 gallons) and full flush when pulled up (1.1 gallons).

The water pressure on the $5^{\text {th }}$ floor $\left(<30\right.$ psi) is less than half the pressure on the $7^{\text {th }}$ floor ( $>80 \mathrm{psi}$ ). The measured water savings post-retrofit was lower on the $5^{\text {th }}$ floor than the $7^{\text {th }}$ floor. The differences in water pressure may have had an impact on the quantity of water used per floor.

The second floor water use was examined prior to and following the toilet fixture retrofit. This floor is where conference rooms for non-building occupants are available for use, thus occupancy is highly variable. The 3-day average volume per flush event was higher postretrofit ( 0.79 gallons per event), in contrast to pre-retrofit ( 0.57 gallons per event). There were $40 \%$ more flush events post retrofit, which impacted the findings.

Water use in the third floor fitness center was also measured for a limited number of days. Because of water line accessibility, only water use on the men's side of the fitness center was measured and from that the total fitness center water use was estimated. Using the limited data collected, the fitness center shower water use is approximately $2 \%$ of the whole building water use.

Overall water use in the Wynkoop Building is below the industry baseline and GSA expectations. The dual flush fixture replacement appears to have resulted in additional water savings that are expected to show a savings in the total annual water use. 


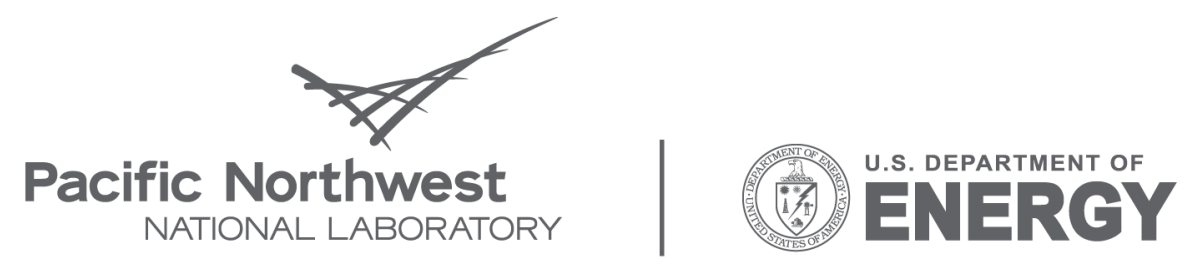

Proudly Operated by Battelle Since 1965

902 Battelle Boulevard

P.O. Box 999

Richland, WA 99352

1-888-375-PNNL (7665)

www.pnl.gov 